\title{
PENGARUH MINAT DAN KEBIASAAN BELAJAR TERHADAP HASIL BELAJAR BIOLOGI SISWA SMA SE-KOTA STABAT
}

\author{
1Muhammad Hasyim Ansyari Berutu (nawtybio@gmail.com ) \\ Muhammad Iqbal H. Tambunan (iqbaltambunan@yahoo.co.id) \\ ${ }^{1}$ Sekolah Tinggi Ilmu Kesehatan (STIKES) Putra Abadi Langkat \\ Jalan R. Suprapto no.10 Kwala Bingai, Stabat Kab.Langkat.
}

\begin{abstract}
ABSTRAK
Penelitian ini bertujuan untuk mengetahui pengaruh minat siswa dan kesiapan belajar terhadap hasil belajar biologi siswa SMA di Kota Stabat. Penelitian ini dilakukan di SMA Negeri Se-Kota Stabat pada tahun 2015. Metode penelitian adalah penelitian eks post facto dengan sampel penelitian sebanyak 155 siswa yang ditentukan secara purposive cluster random sampling (sampel acak kelompok) yaitu 83 siswa dari kelompok SMA negeri dan 72 siswa dari kelompok SMA Swasta. Instrumen penelitian menggunakan angket yang berjumlah 42 item pernyataan. Analisis data menggunakan uji korelasi dan regresi pada taraf siginfikan =0,05 dengan bantuan aplikasi komputer SPSS ver.20,0. Hasil penelitian dan pengujian analisis korelasi menunjukkan: (1) Terdapat pengaruh minat terhadap hasil belajar biologi siswa SMA $(r=0,451 ; P=0,000)$. (2) Terdapat pengaruh kebiasaan belajar terhadap hasil belajar biologi siswa SMA $(r=0,045 ; P=0,000)$. Tindak lanjut dari hasil penelitian ini diharapkan kepada seluruh Tenaga Pendidik khusus mata pelajaran Biologi untuk lebih meningkatkan kemampuan, keterampilan dan motivasinya dalam meningkatkan minat belajar biologi siswa, dan dengan bantuan keluarga bekerja sama meningkatkan kebiasaan belajar siswa untuk meningkatkan hasil belajar.
\end{abstract}

Kata Kunci: Minat, Kesiapan Belajar, Hasil belajar biologi, SMA se-Kota Stabat

\begin{abstract}
This study aims to know the effect of the interest of student and learn readiness toward biology learning outcome of student in senior high school at Stabat city. This study conducted in every state senior high school at Stabat city in the year 2015. The study method is the research of ex post facto with study sample as much as 155 student which defined according purposive cluster random sampling was 83 student from the state senior high school group and 72 student from the private senior high school group. The study instruments using questionnaire which amount 42 items of statement. The data analysis using correlation test and regression of the significance level is 0,05 with using the spss computer application 20.0. The study result and correlation analysis tests show that are: (1) There is of the effect of interest toward biology learning outcome of student in senior high school $(r=0,451 ; P=0,000)$; and (2) There is of the effect of learn readiness toward biology learning outcome of student in senior high school $(r=0,045$, $P=0,000$ ). The follow-up to the result of this study hoped to the whole teaching staffs specifically to the subjects of biology to improve the ability, skills and its motivation in improve the biology learning interest of student, with the help of households collaborate to improve the student learning habits to the improve learning outcome.
\end{abstract}

Keywords: Interest, Learn Readiness, Learning Outcome

\section{PENDAHULUAN}

Pendidikan menengah adalah salah satu tingkatan pendidikan bagi siswa untuk melakukan kegiatan/ aktifitas belajar. Pendidikan menengah diselenggarakan untuk melanjutkan dan meluaskan pengetahuan yang telah didapat di sekolah dasar dan menengah pertama, selain itu juga guna menyiapkan peserta didik menjadi anggota masyarakat yang mampu melaksanakan hubungan timbal balik dengan sosial, budaya dan alam sekitarnya serta dapat mengembangkan kemampuannya lebih lanjut di dunia kerja atau melanjutkan ke perguruan tinggi. Salah satu pendidikan menengah adalah Sekolah Menengah Atas (SMA) yang bertujuan sebagai dasar untuk anak didik dalam mempersiapkan guna melanjutkan ke perguruan tinggi dan atau menyiapkan anak didik yang siap kerja.

Pendidikan yang terjadi di SMA juga merupakan suatu proses belajar yang berupa 
usaha mengumpulkan informasi yang dilakukan secara sadar untuk memperoleh perubahan yang berupa perubahan tingkah laku, sikap, kebiasaan, ilmu pengetahuan dan keterampilan sebagai hasil interaksi dengan lingkungannya yang dikenal sebagai hasil belajar.

Biologi merupakan cabang sains yang ada dalam jurusan IPA untuk SMA. Biologi berkaitan dengan cara mencari tahu dan memahami tentang alam secara sistematis, sehingga biologi bukan hanya sekedar penguasaan kumpulan yang berupa fakta, konsep atau prinsip saja tetapi juga merupakan proses penemuan.

Berdasarkan hasil pengamatan pendahuluan untuk data nilai rata-rata siswa kelas XI Jurusan IPA di SMA Negeri dan Swasta di kota diperoleh nilai rata-rata mata pelajaran Biologi sebesar 73,8. Dari data nilai Biologi tersebut, permasalahan yang ditemukan dari hasil wawancara dengan siswa dibeberapa SMA yang ada di kota Stabat adalah siswa beranggapan bahwa materi biologi sulit untuk dipahami dan mudah lupa terhadap materi setelah selesai pelajaran biologi. Hal ini disebabkan banyaknya jumlah pokok bahasan yang harus dipelajari sedangkan waktu yang tersedia terbatas sehingga guru cenderung memberikan materi tanpa berusaha membangkitkan minat belajar siswa. Selain itu, beberapa siswa mengakui kurang tertarik dengan pelajaran Biologi, menganggap Biologi itu hanya menghafal, sarana dan prasarana yang kurang mendukung kegiatan belajar sehingga pembelajaran juga kurang dikembangkan yang berdampak pada prestasi belajar biologi yang tidak optimal.

Kajian mengenai faktor yang berpengaruh pada prestasi belajar telah lama menjadi perhatian para ahli, guru dan orangtua. Dari berbagai penelitan menempatkan faktor internal menjadi faktor penting, penelitian yang dilakukan Witleni (2012) menyatakan bahwa faktor internal dan faktor eksternal memberi pengaruh baik terhadap hasil belajar biologi siswa IPA di SMAN 1 Linggo Sari Baganti Kabupaten Pesisir Selatan Padang dengan persentase nilai 75,03\% untuk faktor internal dan persentase nilai 71,64\% untuk faktor eksternal.

Faktor-faktor yang memengaruhi hasil belajar saling berkaitan antara yang satu dengan yang lainnya. Kelemahan salah satu faktor akan dapat memengaruhi keberhasilan siswa dalam belajar. Dengan demikian, tinggi rendahnya hasil belajar yang dicapai siswa didukung oleh faktor internal dan eksternal seperti yang telah dikemukakan di atas. Beberapa faktor-faktor internal yang memengaruhi hasil belajar biologi siswa yaitu minat dan kesiapan belajar siswa serta jenis kelamin. Namun dalam penelitian ini dikaji tentang faktor minat dan kesiapan belajar siswa terhadap hasil belajar biologi siswa se Kota Stabat.

\section{HASIL BELAJAR}

Hasil belajar merupakan tolak ukur keberhasilan siswa setelah menempuh proses belajar. Hasil belajar secara umum dapat dikelompokkan ke dalam tiga ranah yaitu ranah kognitif, ranah afektif dan ranah psikomotorik. Evaluasi merupakan skala penilaian yang digunakan dalam menentukan hasil yang diperoleh siswa selama kegiatan pembelajaran di sekolah yang berfokus pada nilai siswa dalam proses pembelajaran di sekolah. Nilai tersebut dinilai dari segi kognitif karena guru sering memakainya untuk melihat penguasaan pengetahuan sebagai pencapaian hasil belajar siswa.

Hasil belajar merupakan bagian terpenting dalam pembelajaran. Sudjana (2009) mendefinisikan hasil belajar siswa pada hakikatnya adalah perubahan tingkah laku sebagai hasil belajar dalam pengertian yang lebih luas mencakup bidang kognitif, afektif dan psikomotorik. Dimyati (2009) juga menyebutkan hasil belajar merupakan hasil dari suatu interaksi tindak belajar dan tindak mengajar.

Dari sisi guru, tindak mengajar diakhiri dengan proses evaluasi hasil belajar. Dari sisi siswa, hasil belajar merupakan berakhirnya pengajaran dari puncak proses belajar. Menurut Winkel (2009), hasil belajar merupakan perubahan dalam pengetahuan, pemahaman, keterampilan dan nilai sikap yang bersifat sangat relatif dan berbekas dari suatu aktifitas mental atau psikis yang berlangsung dalam interaksi aktif dengan lingkungan.

Dari beberapa pendapat tersebut, dapat disimpulkan bahwa hasil belajar adalah penilaian hasil yang sudah dicapai oleh setiap siswa dalam ranah kognitif, afektif dan psikomotor yang diperoleh sebagai akibat usaha kegiatan belajar dan dinilai dalam periode tertentu. Di antara ketiga ranah tersebut, ranah kognitif yang paling banyak dinilai oleh guru di sekolah karena berkaitan dengan kemampuan siswa dalam menguasai isi bahan pelajaran. 
FAKTOR - FAKTOR YANG MEMENGARUHI HASIL BELAJAR

Hasil belajar sebagai salah satu indikator pencapaian tujuan pembelajaran di kelas tidak terlepas dari faktor-faktor yang memengaruhi hasil belajar itu sendiri. Slameto (2010) menyebutkan faktor-faktor yang memengaruhi hasil belajar sebagai berikut: a. Faktor internal adalah faktor yang ada dalam diri individu yang sedang belajar. Faktor internal meliputi: faktor jasmaniah dan faktor psikologis. b. Faktor eksternal adalah faktor yang ada di luar individu. Faktor eksternal meliputi: faktor keluarga, faktor sekolah, dan faktor masyarakat.

\section{Faktor Internal : Kebiasaan Belajar}

Kebiasaan merupakan suatu perilaku yang amat sering diulang sehingga menjadi otomatis dan tidak membutuhkan pemikiran si pelaku, sehingga si pelaku dapat memikirkan hal-hal lain yang lebih menarik ketika ia berperilaku. Hal ini akhirnya menjadi kebiasaan. Kebiasaan belajar bukanlah bakat alamiah atau bawaan sejak lahir dari siswa. Kebiasaan individu tergantung pada tujuan dan cita-citanya, siswa dapat membentuk sendiri kebiasaan belajarnya. Secara umum ada dua kebiasaan belajar yaitu kebiasaan belajar yang baik dan kebiasaan belajar yang kurang baik.

Salah satu tokoh dalam aliran Behaviorisme adalah Thorndike, pendapatnya tentang dasar belajar yaitu asosiasi antara kesan panca indera (sense impression) dengan impuls untuk bertindak (impulse to action). Asosiasi yang demikian disebut Bond atau Connection. Asosiasi atau Bond itulah yang menjadi kuat atau lebih lemah dalam terbentuknya atau hilangnya kebiasaan-kebiasaan. Maka dari itu teori Thorndike disebut dengan Connectionisme atau Bond Psychology. Dari tiga hukum dalam teorinya, yang berkaitan dengan kebiasaan belajar adalah hukum latihan. Prinsip utama belajar adalah latihan (pengulangan), karena itu jika guru sering memberi latihan (S) dan siswa menjawabnya (R), maka prestasi belajar siswa tentang pelajaran tersebut akan meningkat. Thorndike menyatakan bahwa pengulangan tanpa ganjaran tidak efektif, karena asosiasi $\mathrm{S}$ dan $\mathrm{R}$ hanya diperkuat jika diiringi ganjaran. Jadi hukum latihan ini mengarah pada banyaknya pengulangan yang biasa disebut drill (Makmun, 2013).

Kebiasaan belajar merupakan prilaku yang sudah tertanam dalam waktu yang lama dan mempunyai ciri individu dipertegas oleh Aunurrahman (2009) yang berpendapat dalam bukunya "Kebiasaan belajar adalah perilaku seseorang yang telah tertanam dalam waktu yang relatif lama sehingga memberikan ciri dalam aktifitas belajar yang dilakukannya".

Kebiasaan belajar yang baik adalah kebiasaan belajar yang mengandung unsur positif serta sesuai norma yang berlaku. Sedangkan kebiasaan belajar yang tidak baik adalah kebiasaan belajar yang mengandung unsur negatif, serta tidak sesuai dengan norma yang berlaku. Kebiasaan belajar yang positif diantaranya pengaturan jadwal belajar, baik di sekolah maupun di rumah, hal ini sesuai dengan hasil penelitian Kunal dalam Ukpong (2013) yaitu mengenai jam belajar mandiri. Siswa yang memiliki jam belajar lebih lama (di atas 1 jam) memiliki hasil belajar yang lebih baik. Kemudian memilih tempat belajar yang baik, belajar dengan menggunakan berbagai sumber, membaca secara baik dan sesuai dengan kebutuhan, bertanya untuk hal-hal yang tidak diketahui pada guru, teman atau siapa pun. Sedangkan kebiasaan yang kurang baik dalam belajar diantaranya suka menunda-nunda tugas, mengulur-ulur waktu, tidak suka bertanya untuk hal-hal yang tidak diketahui dan sebagainya.

\section{Faktor Internal : Minat Belajar}

Minat merupakan suatu kegiatan yang dilakukan oleh siswa secara tetap dalam melakukan proses belajar. Hilgrad dalam Slameto (2010) menyatakan "Interest is persisting tendency to pay attention to and enjoy some activity and content." Minat adalah kecenderungan yang tetap untuk memperhatikan dan mengenang beberapa kegiatan. Kegiatan yang diminati diperhatikan terus menerus dengan disertai rasa senang dan diperoleh rasa kepuasan. Lebih lanjut dijelaskan minat adalah suatu rasa suka dan ketertarikan pada suatu hal atau aktifitas tanpa ada yang menyuruh. Maka dalam dikatakan minat adalah kecenderungan dalam diri individu untuk tertarik pada suatu objek atau menyenangi suatu objek.

Minat mempunyai pengaruh yang besar terhadap proses dan pencapaian hasil belajar. Apabila materi pelajaran yang dipelajari tidak sesuai dengan minat siswa, maka siswa tidak akan tertarik untuk belajar dengan sebaik-baiknya. Tidak ada daya tarik bagi siswa mengakibatkan keengganan belajar. Keengganan belajar mengakibatkan tidak adanya kepuasan dari 
pelajaran tersebut. Namun sebaliknya, pelajaran yang menarik siswa, lebih mudah direncanakan karena minat menambah aktifitas belajar.

Menurut Djamarah (2002) indikator minat belajar yaitu rasa suka/senang, pernyataan lebih menyukai, adanya rasa ketertarikan adanya kesadaran untuk belajar tanpa di suruh, berpartisipasi dalam aktivitas belajar, memberikan perhatian.

Menurut Crow \& Crow dalam Putra (2012) ada beberapa faktor yang mempengaruhi minat, faktor-faktor tersebut adalah sebagai berikut: 1) The Factor Inner Urge: Rangsangan yang datang dari lingkungan atau ruang lingkup yang sesuai dengan keinginan atau kebutuhan seseorang akan mudah menimbulkan minat; 2) The Factor Of Social Motif: Minat seseorang terhadap objek atau sesuatu hal. Disamping itu juga dipengaruhi oleh faktor dari dalam diri manusia dan oleh motif sosial, misal seseorang berminat pada prestasi tinggi agar dapat status sosial yang tinggi pula; 3) Emosional Factor: faktor perasaan dan emosi ini mempunyai pengaruh terhadap objek misalnya perjalanan sukses yang dipakai individu dalam suatu kegiatan tertentu dapat pula membangkitkan perasaan senang dan dapat menambah semangat atau kuatnya minat dalam kegiatan tersebut. Sebaliknya kegagalan yang dialami akan menyebabkan minat seseorang berkembang.

Menurut Elizabeth Hurlock (dalam Susanto, 2013) mengemukakan bahwa minat belajar merupakan hasil dari pengalaman belajar, bukan hasil bawaan sejak lahir. Hurlock juga menekankan pentingnya minat, bahwa menjadi sumber motivasi kuat bagi seseorang untuk belajar, minat juga menambah kegembiraan pada setiap kegiatan yang ditekuni seseorang, secara keseluruhan pada masa anak-anak minat memberikan sebuah kekuatan untuk belajar.

Oleh karena itu, minat merupakan salah satu faktor yang memengaruhi usaha yang dilakukan oleh seseorang. Minat yang kuat akan menimbulkan usaha yang gigih, serius dan tidak mudah putus asa dalam menghadapi tantangan, sebaliknya jika minat seseorang rendah maka usahanya juga rendah bahkan terkesan mengabaikan. Begitu juga dengan minat seorang siswa dalam proses pembelajaran. Jika seorang siswa memiliki rasa ingin belajar, ia akan cepat dapat mengerti dan mengingatnya (Hamalik, 2011).

\section{METODE PENELITIAN}

Penelitian ini dilaksanakan diseluruh SMA Negeri dan SMA Swasta yang berada di kota Stabat, Provinsi Sumatera Utara. Populasi dalam penelitian ini 733 siswa dari seluruh siswa kelas XI IPA yang tersebar di 8 SMA (1 Negeri dan 6 Swasta) di kota Stabat. Sampel dicuplik dengan teknik purposive cluster random sampling. Cluster dalam tingkatan ini merupakan unit sekolah dan purposive berbasiskan apakah sekolah negeri atau swasta. Randomisasi terhadap sekolah dilakukan dengan cara memilih sekolah negeri dan sekolah swasta di kota dan memilih acak dua kelas dari beberapa kelas XI yang ada di masing-masing sekolah.

Jenis penelitian adalah penelitian eks post facto. Untuk memperoleh data yang dibutuhkan, maka instrumen penelitian yang digunakan adalah : 1) Angket untuk pengumpulan data siswa (sampel) yang terdiri dari 20 item soal. Berdasarkan skala Likert yang mengandung empat alternatif jawaban. Butir angket merupakan pernyataan positif dan negatif. Untuk pernyataan positif, pilihan A diberi skor 4, pilihan B diberi skor 3 , pilihan $\mathrm{C}$ diberi skor 2 , dan untuk pilihan $\mathrm{D}$ diberi skor 1 . Untuk pernyataan negatif, pilihan $\mathrm{A}$ diberi skor 1 , pilihan $\mathrm{B}$ diberi skor 2, pilihan $\mathrm{C}$ diberi skor 3, pilihan D diberi skor 4. 2) Dokumentasi dilakukan untuk mengumpulkan data yang bersumber dari arsip dan dokumen yang berada di sekolah. Dalam hal ini berupa data nilai ujian akhir semester genap mata pelajaran biologi kelas XI TA 2013/2014. Kisi-kisi angket faktor internal dan eksternal dapat dilihat pada tabel 1.

\section{Teknik Analisis Data}

Data yang dikumpulkan diolah menggunakan analisis statistik deskriptif dan analisis statistik inferensial. Uji normalitas data dimaksudkan untuk menentukan normal tidaknya distribusi data penelitian dengan KolmogorovSmirnov. Data berdistribusi normal apabila Sig > 0,05 . Uji homogenitas data dimaksudkan untuk mengetahui perbedaan varians data, dengan Levene's Test. Data homogen jika nilai Sig > 0,05. Uji linieritas data dimaksudkan untuk mengetahui apakah data berdistribusi pola linier. diuji dengan uji $F$, apabila nilai $r$ lebih kecil atau sama dengan dari tingkat $\alpha(\mathrm{Sig}<0,05)$ maka data berdistribusi pola linier Kemudian data skor angket siswa yang dikelompokkan berdasarkan faktor internal 
Tabel 1. Kisi-kisi Angket Faktor Internal Siswa.

\begin{tabular}{|c|c|c|c|c|c|}
\hline \multirow{2}{*}{ No } & \multirow{2}{*}{ Variabel } & \multirow{2}{*}{ Indikator } & \multicolumn{2}{|c|}{ Pernyataan } & \multirow{2}{*}{$\begin{array}{c}\text { Jumlah } \\
\text { Soal }\end{array}$} \\
\hline & & & Positif & Negatif & \\
\hline \multirow{3}{*}{1} & \multirow{3}{*}{$\begin{array}{l}\text { Minat } \\
\text { Belajar }\end{array}$} & Perhatian terhadap bahan pelajaran & 6 & 5 & 2 \\
\hline & & Ketertarikan terhadap bahan pelajaran & $2,3,4$ & $7,8,9$ & 6 \\
\hline & & Rasa senang terhadap pelajaran & 11 & 20 & 2 \\
\hline \multirow{4}{*}{2} & \multirow{4}{*}{$\begin{array}{c}\text { Kebiasaan } \\
\text { Belajar }\end{array}$} & Suasana belajar di rumah dan konsentrasi belajar & 12,16 & 10 & 3 \\
\hline & & Adanya dorongan dan kebutuhan dalam belajar & 14,17 & 13,18 & 4 \\
\hline & & Membaca buku & 15 & 1,19 & 3 \\
\hline & & TOTAL & 10 & 10 & 20 \\
\hline
\end{tabular}

(skor minat belajar, skor kebiasaan belajar) akan dianalisis menggunakan rumus korelasi dan regresi dengan bantuan SPSS 19.

\section{HASIL PENELITIAN}

\section{Deskripsi Minat Belajar Siswa}

Berdasarkan data minat belajar siswa didapatkan skor minat belajar siswa termasuk kategori sedang 29,26 $\pm 0,28(\bar{x} \pm$ SB) dengan skor terendah 18 dan skor tertinggi 39. Berdasarkan hasil uji normalitas, data angket berdistribusi normal $(Z=1,334$; Sig $=0,057)$, varians data angket juga homogen ( $\operatorname{sig}=0,356)$ dan data berpola linier $(F=0,463$; sig $=0,976)$.

\section{Deskripsi Kebiasaan Belajar Siswa}

Berdasarkan data kebiasaan belajar siswa didapatkan skor kebiasaan belajar siswa termasuk kategori sedang 25,66 $\pm 0,30(\bar{x} \pm$ SB) dengan skor terendah 18 dan skor tertinggi 37. Berdasarkan hasil uji normalitas, data angket berdistribusi normal $(Z=1,334$; Sig $=0,057)$, varians data angket juga homogen ( $\operatorname{sig}=0,055)$ dan data berpola linier $(\mathrm{F}=0,463$; $\operatorname{sig}=0,593)$.

\section{PENGUJIAN HIPOTESIS}

Pengaruh Minat Terhadap Hasil Belajar Biologi Berdasarkan hasil analisis data minat belajar siswa berkorelasi positif tetapi lemah ( $\mathrm{r}=$ 0,451) dengan hasil belajar. Dengan nilai P 0,000 < 0,05 maka hipotesis nihil $\left(\mathrm{Ho}_{1}\right)$ yang menyatakan tidak terdapat pengaruh minat terhadap hasil belajar biologi siswa SMA ditolak, sehingga hipotesis alternatifnya $\left(\mathrm{Ha}_{1}\right)$ diterima. Artinya minat berpengaruh terhadap hasil belajar siswa SMA se-kota Stabat.

Nilai koefisien korelasi sebesar 0,451 sehingga harga koefisien determinan minat belajar siswa sebesar 45,1\%. Koefisien arah regresi antara variabel minat belajar dengan hasil belajar diperoleh sebesar 0,230, konstanta (a) sebesar 19,770 .

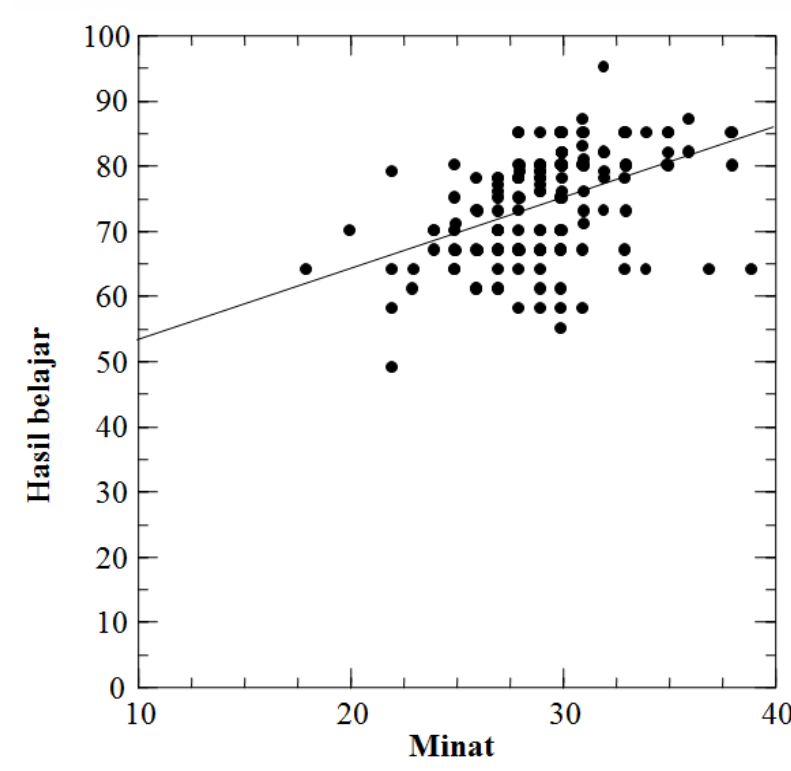

Gambar 1. Pengaruh minat terhadap hasil belajar siswa $(r=0,451 ; P=0,000)$.

\section{Pengaruh Kebiasaan Belajar Terhadap Hasil Belajar Biologi}

Berdasarkan hasil analisis data kebiasaan belajar berkorelasi positif tetapi lemah $(r=0,045)$ dengan hasil belajar. Dengan nilai P 0,000 $<0,05$ maka hipotesis nihil $\left(\mathrm{Ho}_{2}\right)$ yang menyatakan tidak terdapat pengaruh kebiasaan belajar terhadap hasil belajar biologi siswa SMA se-kota Stabat ditolak, sehingga hipotesis alternatifnya $\left(\mathrm{Ha}_{2}\right)$ diterima. Artinya kebiasaan belajar berpengaruh terhadap hasil belajar siswa SMA se-kota stabat tahun 2014.

Nilai koefisien korelasi sebesar 0,529 sehingga harga koefisien determinan kebiasaan belajar siswa sebesar 52,9 \%. Koefisien arah regresi antara variabel kebiasaan belajar dengan hasil belajar diperoleh sebesar 0,452, konstanta (a) sebesar 19,770 . 


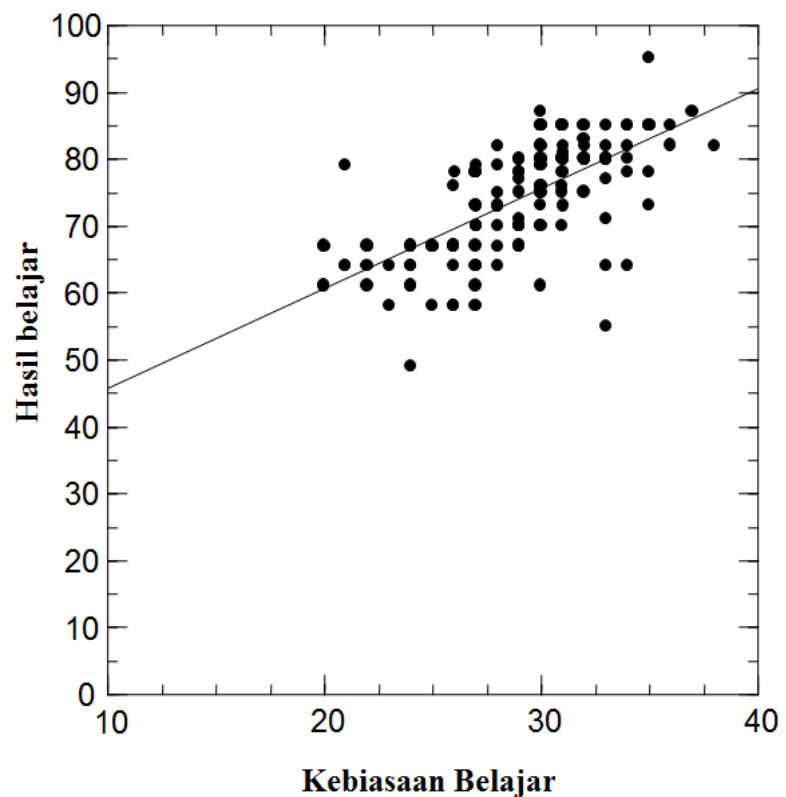

Gambar 2. Pengaruh kebiasaan belajar terhadap hasil belajar siswa $(\mathrm{r}=0,045 ; \mathrm{P}=0,000)$.

\section{PEMBAHASAN}

Pengaruh Minat Terhadap Hasil Belajar Biologi

Minat belajar yang ada di dalam diri siswa dapat berkembang tergantung pada keinginan siswa tersebut dalam melakukan aktivitas belajarnya. Minat tersebut dapat meningkat menjadi besar apabila hubungan tersebut semakin kuat dan dekat. Minat belajar cenderung menghasilkan prestasi yang tinggi, sebaliknya minat belajar yang kurang akan menghasilkan prestasi belajar yang rendah.

Dari hasil analisis data penelitian nilai koefesien determinasi (R2) diketahui bahwa minat belajar dalam penelitian ini memberikan persentase pengaruh sebesar 20,3\% terhadap hasil belajar biologi siswa. Dengan demikian ada 89,7\% faktor lain yang mempengaruhi hasil belajar siswa. Minat belajar merupakan salah satu diantara faktor internal (faktor dari dalam diri) yang mempengaruhi pencapaian hasil belajar. Sejalan dengan hasil penelitian Binuni (2017), berdasarkan analisis data hasil belajar siswa pada mata pelajaran Biologi di SMA Negeri 2 Tondano membuktikan bahwa minat dapat mempengaruhi hasil belajar siswa.

Untuk memaksimalkan hasil belajar dalam proses pembelajaran hendaknya juga didukung oleh faktor-faktor internal dan eksternal yang lainnya. Hasil penelitian ini sejalan Simbolon (2014) bahwa minat pada dasarnya merupakan perhatian yang bersifat khusus. Siswa yang menaruh minat pada suatu mata pelajaran, perhatiannya akan lebih tinggi dan minatnya berfungsi sebagai pendorong yang kuat untuk terlibat secara aktif dalam kegiatan pembelajaran. Dengan demikian proses belajar dapat berlangsung dengan baik dan siswa pun dapat mencapai tujuan belajar sebagaimana yang diharapkan.

\section{Pengaruh Kebiasaan Belajar Terhadap Hasil Belajar Biologi}

Kebiasaan belajar merupakan cara atau teknik yang menetap pada diri siswa pada waktu menerima pelajaran, membaca buku, mengerjakan tugas, dan pengaturan waktu untuk menyelesaikan kegiatan. Berdasarkan data hasil penelitian diketahui bahwa pada dasarnya siswa-siswi kelas XI SMA di Stabat sudah cukup melaksanakan kebiasaan yang baik dalam belajar. Walaupun masih ada beberapa siswa yang belum membiasakan diri melakukannya. Hal ini terbukti dari jawaban mereka terhadap pernyataanpernyataan dalam angket yang dilihat pada hasil deskripsi variabel kebiasaan belajar pada kategori sedang $(25,66 \pm 0,30)$.

Hasil penelitian ini sejalan dengan penelitian oleh Rahayu, M. M. (2015), Hayati, A. N. (2016), Silitonga, R. M (2015) yang menunjukkan bahwa terdapat pengaruh kebiasaan belajar dengan hasil belajar siswa.

Cara belajar yang tepat akan efektif pula terhadap hasil belajar siswa. Bukan hanya belajar ketika akan ada tes saja. Maka siswa perlu belajar secara teratur setiap harinya dengan pembagian waktu yang baik, memilih cara belajar yang tepat dan cukup istirahat akan meningkatkan hasil belajar. kegiatan belajar yang biasa dilakukan secara teratur dan berkesinambungan dalam kesehariannya yang bersifat tetap akan membantu dalam keberhasilan mencapai hasil belajar yang tinggi. Sebaliknya, apabila siswa tidak mempunyai kebiasaan belajar yang baik, maka dapat mengakibatkan hasil belajar yang dicapainya rendah.

Dengan demikian, semakin baik kebiasaan belajar yang dilakukan oleh siswa maka akan semakin tinggi pula hasil belajar yang dicapainya hal ini juga mengisyaratkan bahwa kebiasaan belajar yang efektif akan berdampak positif terhadap hasil belajar siswa. Demikian pula sebaliknya, kebiasaan belajar yang tidak efektif berdampak negatif terhadap hasil belajar siswa. 


\section{SIMPULAN}

Berdasarkan hasil penelitian yang telah diuraikan, maka diperoleh simpulan bahwa : 1) Terdapat pengaruh dari minat terhadap hasil belajar biologi siswa SMA se-kota Stabat tahun 2014 dengan koefisien arah regresi sebesar 0,203, bentuk hubungan positif dan signifikan; 2) Terdapat pengaruh dari kebiasaan belajar terhadap hasil belajar biologi siswa SMA se-kota Stabat tahun 2014 dengan koefisien arah regresi sebesar 0,452, bentuk hubungan positif dan signifikan.

\section{REFERENSI}

Aunurrahman. 2009. Belajar dan Pembelajaran. Bandung: Alfabeta.

Binuni, J., Kaunang, E. S., \& Sumampouw, H. M. (2017). Hubungan Minat Terhadap Hasil Belajar Siswa Pada Mata Pelajaran IPA Biologi SMA Negeri 2 Tondano. JSME (JURNAL SAINS, MATEMATIKA \& EDUKASI), 5(2), 184-187.

Dimyati. 2009. Belajar dan Pembelajaran. Jakarta: PT. Rineka Cipta.

Djaali. 2008. Psikologi Pendidikan. Jakarta: Bumi Aksara.

Djamarah, Syaiful Bahri. 2002. Psikologi Belajar. Jakarta : PT. Rineka Cipta.

Hamalik, Oemar. 2011. Proses Belajar Mengajar. Jakarta: Bumi Aksara.

Hayati, A. N. 2016. Pengaruh Kebiasaan Belajar dan Perhatian Orang Tua Terhadap Hasil Belajar Kognitif Matematika. BASIC EDUCATION, 5(13), 1-224.

Putra, Ardyansah Jani. 2012. Pengaruh Minat dan Motivasi Siswa Dalam Kegiatan Ekstrakurikuler Seni Musik Terhadap Prestasi Belajar Seni Budaya di SMPN 1 wates. S1 THESIS, UNIVERSITAS NEGERI YOGYAKARTA

http://eprints.uny.ac.id/9917/

Rahayu, M. M. 2015. Pengaruh Kebiasaan Belajar Terhadap Hasil Belajar Matematika Siswa Kelas V SD Negeri Daerah Binaan Ii Kecamatan Ajibarang Banyumas. Doctoral Dissertation, UNIVERSITAS NEGERI SEMARANG. http://lib.unnes.ac.id/22061/1/140141115 $\underline{0 \text {-s.pdf }}$

Silitonga, R. M., \& Siagian, S. 2015. Pengaruh Strategi Pembelajaran dan Kebiasaan Belajar Terhadap Hasil Belajar IPA Terpadu. JURNAL TEKNOLOGI PENDIDIKAN (JTP), $8(1)$.

Simbolon, N. 2014. Faktor-Faktor Yang Mempengaruhi Minat Belajar Peserta Didik. ELEMENTARY SCHOOL JOURNAL PGSD FIP UNIMED, 1(2).

Slameto. 2010. Belajar Dan Faktor-Faktor Yang Mempengaruhinya. Jakarta : Rineka Cipta.

Sudjana, Nana. 2009. Dasar-Dasar Proses Belajar Mengajar. Bandung: Sinar Baru Algensindo.

Susanto, Ahmad. 2013. Teori Belajar dan Pembelajaran di Sekolah Dasar. Jakarta: Kencana prenada media group.

Ukpong, D.E. \& George, I.N. 2013. Length of StudyTime Behaviour and Academic Achievement of Social Studies Education Students in the University of Uyo. INTERNATIONAL EDUCATION STUDIES; VOL. 6, No. 3:172-178.

Winkel, W.S. 2009. Psikologi Pengajaran. Jakarta: Grasindo.

Witleni. 2012. Pengaruh Faktor Internal Dan Eksternal Terhadap Hasil Belajar Biologi Siswa IPA Di SMA N 1 Linggo Sari Baganti Kabupaten Pesisir Selatan. STKIP PGRI Sumatera Barat. 